Print ISSN: 2502-1397 / Online ISSN 2540-8100

https://doi.org/10.32505/j-ebis.v6i2.3549

\title{
ANALISIS FAKTOR PENDORONG MINAT NASABAH DALAM MEMILIH TABUNGAN HAJI DI BANK SYARIAH MANDIRI KANTOR CABANG ACEH
}

\author{
Lika Annisa*, Nurma Sari**, Eka Nurlina*** \\ * Universitas Syiah Kuala, annisalika553@gmail.com \\ ** Universitas Syiah Kuala, nurmasari@unsyiah.ac.id \\ ***Universitas Syiah Kuala, eka.nurlina@unsyiah.ac.id
}

\begin{abstract}
This study aims to partially and simultaneously analyze the influence of service quality, social, promotion and knowledge on customer interest in using Hajj savings at Bank Syariah Mandiri in Aceh. Based on 122 questionnaires distributed to respondents, using probability sampling technique, which is simple random sampling and later analyzed by using multiple linear regression models, the results show that service quality, social, promotion, and knowledge have a simultaneous and partial effect on customer interest in using Hajj savings at Bank Syariah Mandiri in Aceh.
\end{abstract}

Keywords: Service Quality, Social, Promotion, Knowledge, Interest in Using Savings

\begin{abstract}
Abstrak
Penelitian ini bertujuan untuk menganalisis secara parsial dan simultan pengaruh dari variabel faktor kualitas pelayanan, faktor sosial, faktor promosi dan faktor pengetahuan terhadap minat nasabah dalam menggunakan tabungan haji di Bank Syariah Mandiri Aceh. Berdasarkan 122 kuesioner yang disebar kepada responden, dengan menggunakan teknik probability sampling yaitu jenis simple random sampling dan dinalisis menggunakan model regresi linear berganda, didapatkan hasil penelitian yang menunjukkan bahwa kualitas pelayanan, sosial, promosi, dan pengetahuan berpengaruh secara simultan dan parsial terhadap minat nasabah dalam menggunakan tabungan haji di Bank Syariah Mandiri Aceh.
\end{abstract}

Kata Kunci: Kualitas Pelayanan, Sosial, Promosi, Pengetahuan, Minat Menggunakan Tabungan

\section{PENDAHULUAN}

Menunaikan Ibadah Haji adalah impian bagi umat islam di seluruh dunia begitu juga umat muslim di Indonesia. Ibadah haji merupakan salah satu rukun 
Lika Annisa, dkk: Analisis Faktor Pendorong Minat Nasabah Dalam Memilih Tabungan Haji

Islam kelima yang di wajibkan bagi muslim yang mampu. Sebagaimana firma Allah dalam surah Ali Imran ayat 97:

“Mengerjakan haji adalah kewajiban manusia terhadap Allah, yaitu (bagi) orang yang sanggup mengadakan perjalanan ke Baitullah; Barangsiapa mengingkari (kewajiban haji) maka sesungguhnya Allah maha kaya (tidak memerlukan sesuatu) dari semesta alam"

Berdasarkan Global Religius Future di perkirakan pada tahun 2020 umat islam di Indonesia merupakan umat muslim yang paling banyak karena mencapai 209,12 juta jiwa. Hal ini sejalan dengan grafik peningkatan jumlah jamaah haji Indonesia setiap tahunnya terus yang meningkat, dan ini tentunya merupakan potensi besar bagi pelaku usaha travel dan jasa keuangan yang melayani pendaftaran dan keberangkatan haji dan umroh. Fenomena ini di dukung dengan adanya pergeseran style masyarakat muslim kini yang lebih cenderung kepada wisata religi. (Databoks, 2019).

Jumlah jamaah haji dari Indonesia sebanyak 11,56 persen dari jumlah keseluruhan jamaah haji diseluruh dunia dan merupakan negara dengan jumlah jamaah haji terbanyak. Karena tingginya keinginan masyarakat Indonesia untuk melaksanakan ibadah haji maka perbankan syariah sebagai salah satu jasa yang menyediakan produk tabung haji dan umroh berusaha untuk memberikan edukasi, promosi dan peningkatan kualitas layanan terbaik bagi pengguna. (Pelakubisnis, 2019). Tabungan haji di khususkan untuk mempersiapkan dana haji dan tidak dapat dicairkan untuk kegunaan yang lain. Aceh merupakan salah satu provinsi dengan umat muslim terbanyak dan provinsi yang telah menerapkan hukum syariat di Indonesia memiliki jamaah haji sebanyak 4.393 di tahun 2018 dan mendapatkan tambahan kuota di tahun 2019 sebanyak 4.466 jamaah.

Mayoritas penduduk Aceh adalah beragama islam dan ini menjadi keuntungan bagi pihak perbankan syariah yang memiliki cabang di Aceh. Bank Mandiri Syariah adalah bank syariah yang nasabah tabungan haji nya mengalami 
peningkatan sejak tahun 2015-2019. Adapun data jumlah jamaah haji Bank Syariah Mandiri dapat di lihat pada tabel berikut:

Table 1. Jumlah Nasabah Tabungan Haji Bank Syariah Mandiri Kantor Cabang Aceh

\begin{tabular}{ccc}
\hline No. & Tahun & Jumah Nasabah \\
\hline 1 & 2015 & 6.575 \\
2 & 2016 & 7.457 \\
3 & 2017 & 8.443 \\
4 & 2018 & 9.218 \\
5 & 2019 & 10.932 \\
\hline
\end{tabular}

Sumber: Bank Syariah Mandiri,2019

Berdasarkan Tabel 1 menunjukkan bahwa nasabah tabungan haji di mandiri syariah kantor cabang di Aceh terus meningkat setiap tahunnya. Pada tahun 2015 sebnayak 6.575 nasabah, pada tahun 2016 sebanyak 7.457 nasabah, selanjutnya pada yahun 2018 dan 2019 juga mengalami peningkatan dan pada tahun 2019 mencapai 10.932 nasabah. Ini menunjukkan adanya faktor pendorong masyarakat memilih produk tabungan haji pada Bank Syariah Mandiri guna persiapan haji mereka dimasa mendatang.

Terdapat beberapa faktor yang memepengaruhi minat seseorang dalam memilih barang dan jasa, begitu pula halnya dengan produk perbankan. Terdapat banyak faktor yang mempengaruhi minat secara positif dan signifikan diantaranya pelayanan, promosi, sosial budaya dan produk (Erlita, 2016). Penelitian terkait faktor minat nasabah dalam menabung juga sebelumnya telah banyak di kemukakan oleh (Yayan, 2010; Susanto, 2021; dan Wardani ,2013). Namun, penelitian ini mencoba melihat lebih spesifik dari tabungan yakni minat menabung tabungan haji dengan menambahkan variabel pengetahuan sebagai variabel minat selain pelayanan, social dan promosi. Dengan tujuan untuk mengetahui apakah faktor pendorong minat mempengaruhi nasabah dalalm memilih tabungan haji. 
Lika Annisa, dkk: Analisis Faktor Pendorong Minat Nasabah Dalam Memilih Tabungan Haji

\section{LANDASAN TEORITIS}

\section{Perbankan Syariah}

Terdapat dual system pada pengoperasian perbankan yaitu sistem syariah dan konvensional. Bank Syariah merupakan bank yang melaksanakan aktivitasya atau kegiatan keuangann yang berdasarkan ketentuan syariat. Prinsip-prinsip dalam menjalan kan kegiatan usaha tersebut telah diatur oleh fatwa MUI. Dalam bertransakasi atau segala kegiatan keuangan di bank syariah tidak boleh terdapat unsur-unsur yang diharamkan seperti riba, ghara, maysir, dan obyek haram lainnya (OJK, 2017).

\section{Tabungan Haji}

Tabungan Haji sangat disarankan bagi masyarakat yang berkeinginan untuk ke Tanah Suci. Tabungan Haji adalah suatu produk seperti tabungan yang lainya tetapi menggunakan akad wadiah dan mudharabah muthlaqah. Masyarakat yang mememiliki keuangan yang kurang berkecukupan dan memiliki banyak kebutuhan hidup lainya yang mesti dipenuhi butuh waktu lama untuk mengumpulkan dana dalam melaksanakan Ibadah Haji.

\section{Tabungan Haji Mabrur Bank Syariah Mandiri}

Tabungan Mabrur adalah tabungan investasi yang ditujukan untuk membantu masyarakat dalam mengatur rencana perjalanan haji maupun umrah. Manfaat yang didapatkan dari memilih tabungan mabrur ini adalah aman dan terjamin untuk melakukan setor online diseluruh cabang Bank Syariah Mandiri. Akad yang dipakai adalah akad mudharabah muthlaqah.

Tabungan mabrur juga memiliki fasilitas pembukaan tabungan mabrur di seluruh outlet Bank Syariah Mandiri, online via Mobile Banking Bank Syariah Mandiri dan di jaringan LSB Bank Mandiri (mandirisyariah, 2017).

\section{Akad Mudharabah Muthlaqah}

Akad mudharabah merupakan kerja sama yang dilakukan oleh dua individu yaitu pemilik dana dan pengelola dana dalam melaksanakan sebuah kegiatan usaha yang keuntungannya akan dibagi dengan berdasarkan bagi hasil yang disepakati bersama antara pihak pemilik dana dengan pengelola usaha. 
Akad mudharabah digunakan di dalam dunia perbankan syariah. Bank syariah Mandiri menerapkan akad mudharabah didalam produk perbankannya khususnya pada tabungan haji yang menggunakan akad mudharabah mutlaqah.

\section{Minat Nasabah}

Minat (interest) adalah situasi dimana seseorang sebelum melakukan sebuah tindakan. Minat muncul dari segi kejujuran dalam melakukan sebuah aktifitas yang menyebabkan timbul adanya ketertarikan pada suatu hal (Azmi dan Muhammad, 2019). Minat merupakan sebuah keinginan yang lahir dari dalam diri yang menjadikan sumber motivasi dalam mendorong kita untuk melakukan hal yang kita inginkan saat diberikan kebebasan untuk melakukan sesuatu. Minat secara umum juga diartikan sebagai sebuah perhatian yang terdapat unsur-unsur perasaan didalamnya.

\section{Faktor-Faktor Yang Mempengaruhi Minat}

Dalam penelitian Erlinda dan Ritonga (2013) faktor pelayanan, promosi, dan sosial memberikan pengaruh secara signifikan kepada minat nasabah dalam menabung. Kemudian dalam penelitian Ulfa (2018) bahwa lokasi, promosi, dan pelayanan juga memberikan pengaruh terhadap nasabah mengambil pembiayaan pada bank syariah.

Lucas dan britt dalan Nurpratama (2014) menyatakan terdapat aspek-aspek dalam minat beli diantaranya;

1. Perhatian (Attention): besarnya perhatian seseorang pada suatu barang maupun jasa

2. Ketertarikan (Interest): timbulnya daya tarik seseorang bagi suatu produk

3. Keinginan (Disire): timbulmya rasa ingin mempunyai suatu produk

4. Keyakinan (Conviction): adanya keyakinan konsumen pada suatu produk dan memutuskan untuk memeperoleh barang tersebut dengan memebeli 
Lika Annisa, dkk: Analisis Faktor Pendorong Minat Nasabah Dalam Memilih Tabungan Haji

\section{Pelayanan}

Pelayanan adalah kegiatan yang diberikan kepada suatu pihak dari pihak lainya yang tak berwujud dan tak melibatkan kepemilikan apapun (Munandar dan Nurma, 2019). Pelayanan dengan kata lain service dapat diklasifikasikan menjadi dua diantaranya 1) high contact service yang merupakan kontak diantara konsumen dan juga penyedia jasa sangat tinggi, dimana konsumen selalu terlihat dalam proses dari layanan jasa yang di sajikan, 2) low contact service, merupakan interaksi yang lemah diantara konsumen dan penyedia jasa, maka jika layanan ini terdapat pada sebuah Lembaga keuangan maka aktifitas ini hanya terjadi interaksi pada tataran front desk.

Kualitas layanan dapat menjadi ukuran seberapa baik tingkat jasa diberikan sesuai dengan harapan konsumen. Persepsi konsumen menjadi pengukur dari baik tidaknya layanan yang di berikan, jika harapan tidak terpenuhi maka tingkat kepuasan akan berkurang begitu pula sebaliknya. Sebuah layanan berkualitas yang di sajikan oleh penyedia layanan akan memberikan kesan baik dari pengguna, sehingga semakin baik kualitas layanan akan menjadi sebab pengguna menggunakan jasa maupun produk yang di tawarkan (Debby,2011)

Menurut Zeithaml et.al dalam Hardian (2015) ada lima unsur yang menjadi indikator pelyanan, yaitu:

1. Berwujud (Tangibles): pelayanan yang berupa sarana fisik seperti perkantoran, ruang tunngu, tempat informasi.

2. Kehandalan (Realibility): kesanggupan dalam menyediakan pelayanan yang terpercaya.

3. Ketanggapan (Responsivess): kesangupan dalam memeberikan pelayanan yang terbaik sesuai permintaan konsumen.

4. Jaminan (Assurance): kesanggupan dalam pengetahuan serta kesopanan para pegawai perusahaan untuk mendapatkan kepercayaan.

5. Empati (Emphaty): tindakan penuh perhatian dan tegas pegawai kepada konsumen 


\section{Promosi}

Menurut Tjiptono dalam ernestivita (2016) promosi pada hakekatnya adalah suatu komunikasi pemasaran, yakni aktifitas pemasaran dengan melakukan menyebarkan informasi, mempengaruhi dan atau meningatkan pasar sasaran atas perusahaan dan produknya agar mau menerima, membeli dan setial pada produk yang ditawarkan perusahaan. Promosi adalah kegiatan pemasaran untuk memberikan informasi terhadap suatu hal kepada para calon pembeli agar mereka terpengaruh atau memperoleh suatu respon dari calon pembeli tersebut (Maghfirah dan Ridwan, 2019).

Indikator promosi dalam penelitian ini sebagaimana dikemukan Kotler dan Amstrong dalam Ernestivita (2016) dalam bauran promosi terdapat elemenelemen yang digunakan sebagai berikut:

1. Iklan (advertising) adalah kegiatan promosi yang dilaksanakan dalam bentuk gambar, tayangan ataupun yang disebarkan secara bentuk brosur, majalah, koran, TV, radio, media sosial.

2. Promosi penjualan (sales promotion) adalah promosi yang dilakukan dalam menaikan jumlah penjualan dalam bentuk kegiatan memberikan potongan harga, memberikan hadiah bagi produk tertentu, dalam waktu tertentu dan tempat tertentu.

3. Publisitas (publicity) yaitu promosi dalam bertujuan untuk memajukan nama perusahaan dengan memberikan berita positif perusahaan dalam kegiatan amal dan sosial serta dalam kegiatan sponsorship.

4. Penjualan personal (personal selling) yaitu kegiatan promosi yang dilakukan dalam bentuk penjualan langsung terhapa konsumen.

\section{Sosial}

Faktor social konsumen merupakan perilaku yang penekanannya pada struktur mencakup suatu tatanan dalam hubungan social dan masyarakat pada posisi social tertentu berdasarkan sistem yang ada dalam masyarakat. Azzahra (2010) menyebutkan keberhasilan Lembaga dalam pemasarannya memerlukan dukungan dari pemehaman faktor social nasabah, dengan mampu memahami 
akan membantu Lembaga dalam merancang sesuatu yang menjadi kebutuhan di masyarakat. sosial adalah suatu hal yang dapat dicapai maupun dapat dihasilkan dari adanya interaksi yang dijalankan sehari hari oleh warga negaranya dan pemerintahannya.

Indikator variabel sosial sebagai berikut:

a) Kelompok Referensi; kelompok yang mampu memepengaruhi seseorang

b) Keluarga; Keluarga sangat berpengaruh terhadap tingkah laku seseorang

c) Peran dan Status: Peran adalah bukti atas posisi maupun kedudukan seseorang didalam lingkungan sosialnya sehingga status nya dalam masyarakat mendapat penghargaan.

\section{Pengetahuan}

Berbagai macam hal yang diperoleh oleh seseorang melalui panca indera disebut pengetahuan (Notoatmodjo, 2010) Pengetahuan diartikan sebagai informasi yang diketahui yang berkaitan dengan suatu hal. Menurut Purwanto (2016) pengetahuan konsumen dibagi dalam tiga macam, yaitu:

1. Pengetahuan Produk; yaitu berbagai informasi yang berkaitan dengan suatu produc yang meliputi merek, kategori produk, harga produk, atribut product.

2. Pengetahuan Pembelian; merupakan infomasi yang diperoleh konsumen untuk mendapatkan produk yang diinginkan.

3. Pengetahuan Pemakaian; suatu produk akan menjadi bermanfaat ketika produk tersebut telah digunakan oleh konsumen secara maksimal dan sebaik mungkin.

Menurut penelitian yang dilakukan oleh Mulyaningtyas, et.al (2021) Pengetahuan mengenai produk dan jasa perbankan memberikan pengaruh yang positif dan signifikan terhadap minat menabung pada perbankan Syariah. 


\section{Kerangka Konseptual}

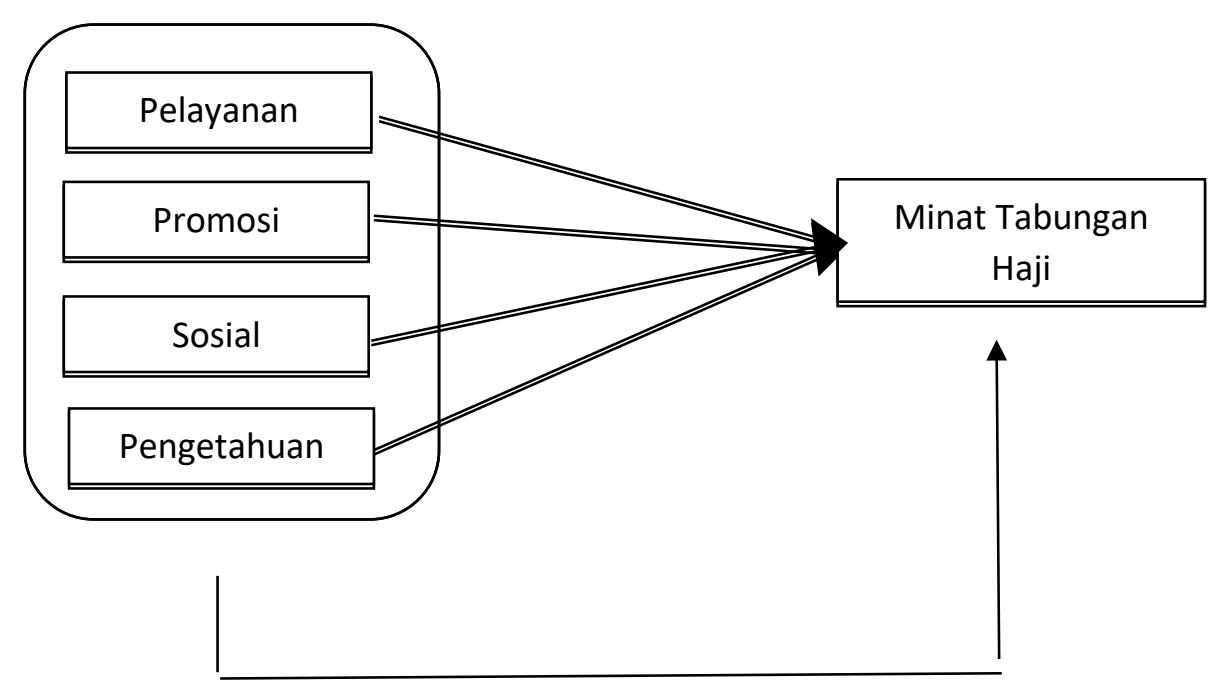

\section{Gambar 1 Model Kerangka Teoritis Penelitian}

Berdasarkan kerangka konseptuan pada gambar 1, Adapun dugaan sementara berdasarkan teori sebagai berikut:

1. Terdapat pengaruh positif dan signifikan antara variabel pelayanan terhadap minat.

2. Terdapat pengaruh positif dan signifikan antara variabel promosi terhadap minat.

3. Terdapat pengaruh positif dan signifikan antara variabel sosial terhadap minat.

4. Terdapat pengaruh positif dan signifikan antara variabel pengetahuan terhadap minat.

\section{METODE}

Penelitian ini menggunakan pendekatan kuantitatif dengan sampel berjumlah 122 nasabah, sampel diperoleh berdasarkan rumus slovin dengan persentase 10 persen. Teknik sampling yang digunakan probability sampling dengan simple random sampling. Data primer di peroleh dengan menyebarkan kuisioner kepada responden, sedangkan data sekunder di peroleh dari sumber- 
Lika Annisa, dkk: Analisis Faktor Pendorong Minat Nasabah Dalam Memilih Tabungan Haji

sumber tertulis baik media cetak maupun elektronik. Data diolah dengan menggunakan uji regresi linier berganda, dengan persamaan sebagai berkut:

$$
M I=\beta_{1} P I+\beta_{2} P r+\beta_{3} S i+\beta_{4} P n+e
$$

Dimana $M$ adalah minat nasabah, $\beta_{1}, \beta_{2}, \beta_{3}, \beta_{4}$ koefesien, PI adalah Kualitas layanan, Pr adalah promosi, Si adalah sosial, dan Pn adalah pengetahuan e adalah error term.

Skala pengukuran yang digunakan dengan menggunakan likert, bertujuan untuk menginterprestasikan seberapa kuat subjek menyetujui dan tidak menyetujui pertanyaan dalam kuisioner. Operasional variabel pada penelitian dapat diringkas pada tabel 2 berikut:

Tabel 2. Operasional Variabel

\begin{tabular}{|c|c|c|c|c|}
\hline No & Variabel & Definisi Variabel & Indikator & Skala \\
\hline \multicolumn{5}{|c|}{ Dependen Variabel } \\
\hline 1 & Minat (MI) & 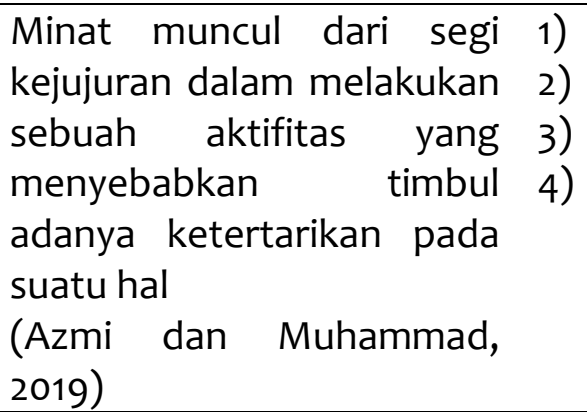 & $\begin{array}{l}\text { Perhatian } \\
\text { Ketertarikan } \\
\text { Keinginan } \\
\text { Keyakinan }\end{array}$ & $1-5$ \\
\hline \multicolumn{5}{|c|}{ Independen Variabel } \\
\hline 2 & $\begin{array}{l}\text { Pelayanan } \\
\text { (PI) }\end{array}$ & $\begin{array}{l}\text { Pelayanan adalah kegiatan } \\
\text { yang diberikan kepada } \\
\text { suatu pihak dari pihak 2) } \\
\text { lainya yang tak berwujud } \\
\text { dan tak melibatkan } \\
\text { kepemilikan apapun } \\
\text { (Munandar dan Nurma, } \\
\text { 2019) }\end{array}$ & $\begin{array}{l}\text { Berwujud } \\
\text { (Tangibles) } \\
\text { Kehandalan } \\
\text { (Realibility) } \\
\text { Ketanggapan } \\
\text { (Responsivess) } \\
\text { Jaminan } \\
\text { (Assurance) } \\
\text { Empati (Emphaty): }\end{array}$ & $1-5$ \\
\hline 3 & Promosi (Pr) & $\begin{array}{lll}\text { Promosi adalah } & \text { kegiatan } & 1 \text { ) } \\
\text { pemasaran untuk } & 2 \text { ) } \\
\text { memberikan informasi } & \\
\text { terhadap suatu hal kepada } & 3 \text { ) } \\
\text { para calon pembeli agar } & \\
\text { mereka terpengaruh atau } & \\
\text { memperoleh suatu respon }\end{array}$ & $\begin{array}{l}\text { Iklan (advertising). } \\
\text { Promosi penjualan } \\
\text { (sales promotion). } \\
\text { Publisitas } \\
\text { (publicity). }\end{array}$ & $1-5$ \\
\hline
\end{tabular}




\begin{tabular}{|c|c|c|c|c|c|}
\hline & & $\begin{array}{l}\text { dari calon pemebeli } \\
\text { tersebut (Maghfirah dan } \\
\text { Ridwan, 2019) }\end{array}$ & 4) & $\begin{array}{l}\text { Penjualan personal } \\
\text { (personal selling) } \\
\text { yaitu }\end{array}$ & \\
\hline 4 & Sosial (Si) & $\begin{array}{l}\text { Sosial adalah suatu hal yang } \\
\text { dapat dicapai maupun } \\
\text { dapat dihasilkan dari } \\
\text { adanya interaksi yang } \\
\text { dijalankan sehari hari oleh } \\
\text { warga negaranya dan } \\
\text { pemerintahannya. } \\
\text { Menurut Lewis(2010) }\end{array}$ & $\begin{array}{l}\text { 1) } \\
\text { 2) } \\
\text { 3) }\end{array}$ & $\begin{array}{l}\text { Kelompok } \\
\text { Referensi; } \\
\text { Keluarga; } \\
\text { Peran dan Status: }\end{array}$ & $1-5$ \\
\hline 5 & $\begin{array}{l}\text { Pengetahuan } \\
\text { (Pn) }\end{array}$ & $\begin{array}{l}\text { berbagai macam hal yang } \\
\text { diperoleh oleh seseorang } \\
\text { melalui panca indera. } \\
\text { Notoatmodjo, S. (2010) }\end{array}$ & $\begin{array}{l}\text { 1) } \\
\text { 2) } \\
\text { 3) }\end{array}$ & $\begin{array}{l}\text { Pengetahuan } \\
\text { Produk } \\
\text { Pengetahuan } \\
\text { Pembelian } \\
\text { Pengetahuan } \\
\text { Pemakaian }\end{array}$ & $1-5$ \\
\hline
\end{tabular}

\section{HASIL DAN PEMBAHASAN}

\section{Karakteristik Responden}

Karakteristik respondennya yang jumlahnya 122 nasabah diklasifikasikan berdasarkan jenis kelamin responden pria sebanyak 57 orang dengan presentasi sebesar $46,7 \%$ dan responden wanita sebanyak 65 orang dengan persentase 53,3. Dari segi usia yang menjadi responden dalam penelitian ini kebanyakan adalah yang berusia >46 Tahun. Sebagian besar responden dalam penelitian ini berstatus PNS yaitu sebanyak 53 orang atau 43,4 persen. Berdasarkan pendidikan terakhirnya responden yang berasal dari lulusan S1 sebanyak 102 responden atau sekitar 83,6. Nasabah yang menggunakan tabungan haji di BSM Kota Banda Aceh didominasi oleh responden dengan pendapatan Rp3.000.000 - Rp5.000.000 sebesar 34,4 persen.

\section{Hasil Uji Kualitas Data}

Pengujian kualitas data didalam peneelitian ini terdiri dari uji validitasa dan uji reliabelitas yang ditujukan untuk menguji instrumen didalam penelitian agar data yang didapatkan dapat dipercaya sehingga berpengaruh bagi hasil penelitian 
Tabel 3. Hasil Uji Validitas

\begin{tabular}{lcccc}
\hline Variabel & Nomor Item & Nilai raing & Nilai rabel & Keterangan \\
\hline Pelayanan (X1) & A1 & 0,637 & 0,178 & Data Valid \\
& A2 & 0,776 & 0,178 & Data Valid \\
& A3 & 0,829 & 0,178 & Data Valid \\
& A4 & 0,784 & 0,178 & Data Valid \\
& A5 & 0,691 & 0,178 & Data Valid \\
& A6 & 0,559 & 0,178 & Data Valid \\
& A7 & 0,633 & 0,178 & Data Valid \\
& A8 & 0,533 & 0,178 & Data Valid \\
\hline Sosial (X2) & B1 & 0,623 & 0,178 & Data Valid \\
& B2 & 0,630 & 0,178 & Data Valid \\
& B3 & 0,373 & 0,178 & Data Valid \\
& B4 & 0,609 & 0,178 & Data Valid \\
& B5 & 0,639 & 0,178 & Data Valid \\
& B6 & 0,562 & 0,178 & Data Valid \\
& B7 & 0,558 & 0,178 & Data Valid \\
& B8 & 0,602 & 0,178 & Data Valid \\
Bromosi (X3) & C1 & 0,598 & 0,178 & Data Valid \\
\hline C2 & 0,745 & 0,178 & Data Valid \\
& C3 & 0,613 & 0,178 & Data Valid \\
& C4 & 0,530 & 0,178 & Data Valid \\
& C5 & 0,761 & 0,178 & Data Valid \\
Pengetahuan & D1 & 0,632 & 0,178 & Data Valid \\
\hline D4) & D2 & 0,6571 & 0,178 & Data Valid \\
& D3 & 0,736 & 0,178 & Data Valid \\
& D4 & 0,740 & 0,178 & Data Valid \\
& D5 & 0,621 & 0,178 & Data Valid \\
& & & 0,178 & Data Valid \\
\hline
\end{tabular}

Dari hasil tersebut dijelaskan bahwa semua yang menjadi item pertanyaan untuk variabel dependen yaitu minat menabung ( $\mathrm{Mi})$ dan variabel independennya pelayanan (Py), Promosi (Pr), Sosial (Ss), dan pengetahuan (Pt) mempunyai nilai korelasi $r_{\text {hitung }}>r_{\text {tabel }}$ yang bernilai 0,178 . Jadi, dapat disimpulkan bahwa semua variabel penelitian adalah valid nilai $r_{\text {hitung }}>0,178$.

Tabel 4. Hasil Uji Reabilitas

\begin{tabular}{cccc}
\hline Variabel & \multicolumn{2}{c}{ Cronbach Alpha } & \multirow{2}{*}{ Keterangan } \\
\cline { 2 - 3 } & Hitung & Standar & \\
\hline Pelayanan & 0,834 & 0,6 & Handal \\
Promosi & 0,741 & & Handal \\
Sosial & 0,668 & & Handal \\
Pengetahuan & 0,678 & & Handal \\
\hline
\end{tabular}

Sumber: Data olah SPSS

Hasil cronbach Alpha dari data X1 hingga X4 antara 0,834 hingga 0,678 lebih tinggi dari 0,6 nilai minimal crobach Alpha yang diharuskan. Sehingga, data tersebut reliabel atau layak digunakan. 


\section{Hasil Uji Regresi Linear Berganda}

Tabel 6. Hasil Uji Regresi Berganda

\begin{tabular}{|c|c|c|c|c|c|}
\hline \multirow[t]{2}{*}{ Model } & $\begin{array}{l}\text { Standardized } \\
\text { Coeffiecients }\end{array}$ & \multirow[t]{2}{*}{$T$} & \multirow[t]{2}{*}{ Sig. } & \multirow[t]{2}{*}{$F$} & \multirow[t]{2}{*}{ Sig. } \\
\hline & Beta & & & & \\
\hline Pelayanan & 0,211 & 2,432 & 0,017 & 10,006 & ,000 \\
\hline Promosi & 0,229 & 2,660 & 0,009 & & \\
\hline Sosial & 0,217 & 2,533 & 0,016 & & \\
\hline Pengetahuan & 0,286 & 3,165 & 0,002 & & \\
\hline \multicolumn{6}{|l|}{$R=0,635$} \\
\hline \multicolumn{6}{|c|}{ R Square $=0,549$} \\
\hline \multicolumn{6}{|c|}{ Adj R Square = 0,529 } \\
\hline
\end{tabular}

Berdasarkan tabel 6 dapat di jelaskan hasil uji regresi linear berganda dalam pesamaan sebagai berikut.

$$
\mathrm{MI}=0,211 \mathrm{PI}+0,229 \mathrm{Pr}+0,217 \mathrm{Si}+0,286 \mathrm{Pn}+\mathrm{e}
$$

Dari hasil persamaan regresi berganda diatas, didapatkan hasil sebagai berikut yaitu:

1. koefisien regresi pada variabel pelayanan (PI) senilai 0,211 yang artinya setiap adanya perubahan terhadap pelayanan sebesar 1 satuan, maka secara relatif akan meningkatkan minat nasabah menggunaakan tabungan haji di BSM sebesar 0,211 atau 21,1 persen. Dengan demikian jika pelayanan terhadap nasabah meningkat, maka minat menabung juga akan ikut meningkat.

2. Koefisien regresi variabel promosi (Pr) sebesar 0,229 artinya setiap adanya perubahan terhadap promosi sebesar 1 satuan, maka secara relatif akan meningkatkan minat menggunakan tabungan haji di BSM sebesar 0,229 atau 22,9 persen.

3. Koefisien variabel Sosial (Si) sebesar 0,217 artinya setiap adanya perubahan terhadap sosial sebesar 1 satuan, maka secara relatif akan meningkatkan minat nasabah dalam menggunakan tabungan haji sebesar 21,7 persen. 
Lika Annisa, dkk: Analisis Faktor Pendorong Minat Nasabah Dalam Memilih Tabungan Haji

4. Koefisien variabel pengetahuan pengetahuan $(\mathrm{Pn})$ sebesar 0,286 artinya setiap adanya perubahan terhadap tingkat pengetahuan sebesar 1 satuan, maka secara relatif dapat meningkatkan minat nasabah dalam mengguanakan tabungan haji di BSM ebesar 0,286 atau 28,6 persen.

\section{Hasil Uji Simultan (Uji F)}

Berdasarkan hasil uji simultan diperoleh hasil $F_{\text {hitung }}$ senilai 10.006 sedangkan $F_{\text {tabel }}$ senilai 2,46 artinya $F_{\text {hitung }}>F_{\text {tabel }}$ pada tingkat signifikansi 0,000. Demikian dapat disimpulkan bahwa menerima hipotesis alternatif ( $\mathrm{Ha}$ ) dan menolak hipotesis nol $\left(\mathrm{H}_{0}\right)$, sehingga pelayanan $(\mathrm{PI})$, Promosi $(\mathrm{Pr})$, Sosial ( $\left.\mathrm{Si}\right)$, dan Pengetahuan (Pn) secara bersama -sama memiliki pengaruh secara signifikan terhadap minat memilih tabungan (Mi).

\section{Hasil Pengujian secara Parsial (Uji t)}

Hasil (uji t) dapat di uraikan sebagai berikut:

1. Hasil penelitian terhadap variabel pelayanan ( $\mathrm{Pl})$ diperoleh $\mathrm{t}$-hitung senilai 2,432 dan t-tabel sebesara 1,980. Sehingga t-hitung $>$ t-tabel dengan tingkat signifikan < $a=0,05$ maka dapat disimpulkan terdapat pengaruh positif signifikan dari variabel pelayanan terhadap minat memilih tabungan dengan tingkat siginifikan sebesar 0,017

2. Hasil penelitian terhadap variabel promosi ( $\mathrm{Pr})$ memperoleh t-hitung senilai 2,533 dan memiliki nilai t-tabel senilai 1,980. Sehingga t-hitung $>$ t-tabel dengan tingkat signifikan $<\alpha=0,05$ maka dapat disimpulkan bahwa terdapat pengaruh positif siginifikan dari variabel promosi terhadap minat nasabah dengan tingkat signifikan sebesar 0,009.

3. Hasil penelitian terhadap variabel sosial ( $\mathrm{Si}$ ) memperolehi t-hitung senilai 2,660 dan t-tabel memiliki nilai senilai 1,980. Sehingga t-hitung $>t$-tabel dengan tingkat signifikan $<a=0,05$ maka diasimpulkan bahwa terdapat pengaruh positif signifikan dari variabel sosial terhadap minat nasabah denga tingkat signifikan sebesar 0,016. 
4. Hasil penelitian terhadap variabel pengetahuan $(\mathrm{Pn})$ memperoleh t-hitung seniali 3,165 dan nilai dari t-tabel sebesar 1,988. Sehingga t-hitung > t-tabel dengan tingkat signifikan $<\alpha=0,05$ maka terdapat pengaruh positif signifikan dari variabel pengetahuan terhadap minat nasabah (Mi) dengan tingkat signifikansi sebesar 0,002.

Dari hasil penelitian di hasilkan bahwa variabel pelayanan, promosi, sosial dan pengetahuan secara simultan memberi pengaruh signifikan terhadap minat nasabah memilih tabungan haji, begitu juga halnya secara parsial keempat variabel independen memberi pengaruh positif dan signifikan. Pelayanan memberikan pengaruh yang positif dan signifikan terhadap minat nasabah memilih tabungan haji pada bank Syariah mandiri, hal ini menunjukkan service yang di berikan selama ini oleh pihak bank sudah baik, sebab service yang prima akan memantik minat seseorang untuk melakukan transaksi. Rasa aman, nyaman serta menyenangkan terwujud dari sebuah pelayanan yang maksimal. Penelitian ini sejalan dengan yang dilakukan oleh (Likamahua,2011; Munandar dan Sari, 2019), kualitas layanan mampu mempengaruhi keputusan, karena kualitas layanan menjadi sebuah ukuran seberapa baik jasa yang diberikan sesuai dengan harapan pengguna/ pelanggan.

Selanjutnya variabel sosial dan promosi juga memberikan sumbangan positif terhadap minat. Promosi dapat dilakukan dengan berbagai cara, selain dengan media cetak maupun elektronik. Pelayanan prima yang dirasakan juga dapat menjadi media promosi berupa mouth to mouth. hasil penelitian ini di dukung oleh teori promosi yang tidak hanya sebagai sarana komunikasi bahkan lebih dari itu dapat berupa alat yang mempengaruhi pengguna dalam kegiatan pembelian baik barang maupun jasa. Penelitian ini sejalan dengan Ernestivita (2016) Selanjutnya variabel pengetahuan pada penelitian ini juga memberikan pengaruh yang positif dan signifikan, artinya nasabah dalam memilih produk perbankan bukan di landasi oleh ikut-ikutan melainkan dengan di bekali pengetahuan, semakin baik pengetahuan seseorang maka akan semakin selektif dan semakin baik memilih produk yang akan digunakan, termasuk 
Lika Annisa, dkk: Analisis Faktor Pendorong Minat Nasabah Dalam Memilih Tabungan Haji

produk layanan perbankan. Sebagaimana penelitian (Purwanto, 2016) mengungkapkan hal senada, bahwa pengetahuan menjadi variabel yang mempengaruhi minat nasabah karena pengetahuan akan produk perbankan akan memberikan rangsangan untuk menggunakan produk maupun jasa yang disediakan. Penelitian lain yang di kemukakan oleh Chotifah (2018) mendapatkan sebuah hasil bahwa pengetahuan tentang office channeling berpengaruh positif dan signifikan terhadap minat menabung di bank Syariah.

\section{SIMPULAN}

1. Variabel pelayanan (PI) terhadap minat memilih nasabah memiliki pengaruh positif signifikan dengan tingkat siginifikan sebesar 0,017

2. Variabel promosi (Pr) terhadap minat memilih nasabah memiliki pengaruh positif siginifikan dengan tingkat signifikan sebesar 0,009.

3. Variabel sosial (Si) terhadap minat memilih nasabah pengaruh positif signifikan dengan tingkat signifikan sebesar 0,016.

4. Variabel pengetahuan $(\mathrm{Pn})$ terhadap memilih minat nasabah memiliki pengaruh positif signifikan dengan tingkat signifikansi sebesar 0,002.

5. Variabel pelayanan (PI), promosi (Pr), sosial ( $\mathrm{Si})$, pengetahuan (Pn) secara simultan memiliki pengaruh secara signifikan terhadap minat memilih tabungan (Mi).

\section{PUSTAKA ACUAN}

Amelya, A. Inilah 10 Bank Syariah Terbaik dan Paling Menguntungkan di Indonesia. Melalui https://www.folderbisnis.com. Diakses 12 Februari 2020

Ariyanti. (2011). Faktor-Faktor Yang Mempengaruhi Minat Nasabah Bertransaksi Di Bank Syariah. Surakarta. [Skripsi] Universitas Muhammadiyah Surakarta.

Astuti, I. R. (2020). Faktor-faktor yang Mempengaruhi Minat Menabung di Bank Syariah Surakarta. Business Innovation and Entrepreneurship Journal, 2(3), 167-172.

Azmi, N \& Riyaldi, H. (2019). Faktor-Faktor Yang Memengaruhi Minat Pengusaha Usaha Mikro, Kecil Dan Menengah (Umkm) Mengajukan Pembiayaan Di Bank Syariah (Studi Kasus pada Bank Syariah Mandiri Kantor (abang Aceh). Jurnal Ilmiah Mahasiswa Ekonomi Islam. Volume 1 Nomor 1. 
Bank Mandiri Syariah. (2017). Sejarah Bank Syariah Mandiri. Melalui https://www.mandirisyariah.co.id. Diakses pada 18 Oktober 2019 2017. Tabungan Mabrur. Melalui https://www.mandirisyariah.co.id. Diakses pada 18 Oktober 2019

BPS. (2019). Jumlah Penduduk Provinsi Aceh 2019. Melalui https://www.bps.go.id. Diakses 20 Desember 2019.

Chotifah, Y. S. (2018). Peningkatan Minat Menabung Di Bank Syariah Melalui Program Office Channeling. Journal of Finance and Islamic Banking, 1(1), 65-75

Effendi, L. (2009). Analisis Faktor-Faktor Yang Mempengaruhi Pengambilan Keputusan Nasabah Pada Bank Muamalat Malang. Laporan Penelitian

Erlinda, V., \& Ritonga, H. D. H. (2013). Analisis faktor-faktor yang mempengaruhi pemilihan bank oleh nasabah tabungan haji (Studi kasus: Peserta bimbingan manasik haji Aziziah kec. Medan Johor). Jurnal Ekonomi dan Keuangan, 1(3), 14726.

Ernestivita, G. (2016) Analisis Pengaruh Place, Promotion, Dan People Terhadap Keputusan Konsumen Melakukan Pembelian Produk Pasar Modal Dengan Menggunakan Jasa Equity Brokerage Di Pt Sucorinvers Central Gani Cabang Kediri. Jurnal Nusamba, 1(2), 10-20

Fauzi, Y. (2010). Faktor-Faktor Yang Mempengaruhi Nasabah Menabung Di Perbankan Syariah (KasusPada Bank BNI Syariah Kantor Cabang Yogyakarta). Yogyakarta. [Skripsi]. Universitas Islam Negeri Sunan Kalijaga

Irawan. 2009. Analisis Faktor-Faktor Yang Mempengaruhi Minat Nasabah Dalam Memutuskan Menabung di Bank Syariah Mandiri Cabang Malang. Malang. Skripsi S-1. Universitas Islam Negri Malang.

Kusnandar, Viva Budy. (2019). Indonesia, Negara dengan Penduduk Muslim Terbesar Dunia. Melalui https://databoks.katadata.co.id. Diakses 13 Januari 2020

Likumahua, D. (2011) Faktor Kualitas Layanan serta Pengaruhnya Terhadap Kepuasan dan Loyalitas Nasabah Perbankan di Ambon.

Maghfirah, L \& Ridwan N. (2019). Analisis Faktor-Faktor Yang Mempengaruhi Minat Nasabah Menggunakan Produk Rahn Pada Pegadaian Syariah (Studi Kasus pada Kantor Pusat Pegadaian Syariah Kota Banda Aceh). Jurnal Ilmiah Mahasiswa Ekonomi Islam. Volume 1 Nomor 1.

Mulyaningtyas, I. F., Soesatyo, Y., \& Sakti, N. C. (2020). Pengaruh Pengetahuan Tentang Bank Syariah Dan Literasi Keuangan Terhadap Minat Menabung Siswa Pada Bank Syariah Di Kelas XI IPS MAN 2 Kota Malang. Jurnal Ekonomi Pendidikan Dan Kewirausahaan, 8(1), 53-66.

Munandar, A \& Sari, N. (2019). Pengaruh Religiusitas, Kualitas Pelayanan, Kualitas Produk Terhadap Loyalitas Nasabah Tabungan Pada PT. Bank Aceh Syariah Kantor Cabang Pembantu Darussalam. Al-Muamalat Jurnal Hukum dan Ekonomi Syariah. Vol IV, No 02

Ningsih, S. W., \& Sari, N. (2020). Pengaruh Dimensi Kualitas Pelayanan Dan Nisbah Bagi Hasil Terhadap Kepuasan Nasabah Bank Syariah Mandiri Cabang Meulaboh. Jurnal Ilmiah Mahasiswa Ekonomi Islam, 2(2). 
Lika Annisa, dkk: Analisis Faktor Pendorong Minat Nasabah Dalam Memilih Tabungan Haji

Notoatmodjo, S. (2010) Promosi Kesehatan Teori an Aplikasi. Jakarta: Rineka Ilmu

Nurpratama, P H. (2014) Pengaruh Product Placement Terhadap Minat Beli. [skripsi] Yogyakarta: UIN Sunan Kalijaga

OJK. (2019). Statistik Perbankan Syariah. Melalui https://www.ojk.go.id. Diakses 2 Maret 2020

Oktarin, Erlita. (2016). Faktor-Faktor Yang Mempengaruhi Keputusan Nasabah Membuka Tabungan Haji Di Bank Muamalat Indonesia Cabang Sungailiat STUDIA: Jurnal Hasil Penelitian Mahasiswa, 1(1), 64-74

Pelaku Bisnis. (2019). Pemerintah Tingkatan Pelayanan Penyelenggaraan Haji dan Umrah. Melalui https://pelakubisnis.com. Diakses 15 November 2019

Purwanto, A. (2016). Pengaruh Pengetahuan, Religiusitas dan Tingkat Pendapatan Terhadap Minat Masyarakat Menabung di Bank Syariah Boyolali (Doctoral dissertation, IAIN SALATIGA).

Putri, S., Noor, M., \& Suharto, S. (2021). Pengaruh Kecerdasan Intelektual, Kecerdasan Emosional Dan Kecerdasan Spiritual Terhadap Loyalitas Nasabah Pada Bank Mandiri Kcp Way Jepara Kabupaten Lampung Timur. Simplex: Journal of Economic Management, 2(2), 81-91.

Sitorus, Ropesta. (2019). BRI Syariah Layani Hampir 10.000 Nasabah dalam Dua Hari Pelunasan Biaya Haji. Melalui https://finansial.bisnis.com. Diakses 24 Juni 2020

. (2019). Pacu DPK dari Dana Haji, Ini Strategi Mandiri Syariah. Melalui https://finansial.bisnis.com. Diakses 24 Juni 2020

Susanto, R. (2021). Keputusan Nasabah Dilihat dari Kualitas Layanan dan Promosi Pada PT. Bank BPR Cincin Permata Andalas Cabang Padang. Jurnal Pundi, 5(2).

Ulfa, M. (2018). Analisis Pengaruh Promosi, Lokasi Serta Pelayanan Terhadap Keputusan Pengambilan Pembiayaan Kur Dengan Minat Nasabah Sebagai Variabel Intervening (Doctoral Dissertation, lain Salatiga).

Vuong, B. N et.al (2020). Factors Affecting Saving Deposit Decision of Individual Costumers: Empirical Evidence from Vietnamese Commercial Banks. Journal af Asian Finance Economics and Business, 7(7), 293-302 . DOI: 10.13106/jafeb.2020.vol7.no.7.293

Wardani, A (2013). Pengaruj Kepercayaan, Pelayanan dan Fasilitas Bank Terhadap Perilaku Menabung (Studi pada Nasabah Bank Purworejo)

Yogiarto, Atanasius H. P. (2015) Pengaruh Bahi Hasil, Promosi dan Kualitas Pelayanan Terhadap Keputusan Penggunaan Jasa Perbankan Syariah Tabungan Mudharabah (Studi Kasus Pada Nasabah Bank Muamalat Pekalongan. Yogyakarta [Skripsi] Universitas Negeri Yogyakarta 